Journal of Teacher Education for Sustainability, vol. 22, no. 2, pp. 104-120, 2020

\title{
The Impact of Spaced and Massed Instruction on Foreign Language Reading Motivation and Reading Attitude among Pre-intermediate EFL Learners
}

\author{
Ehsan Namaziandost \\ Islamic Azad University, Shahrekord, Iran \\ Maryam Khodaverdian Dehkordi \\ Yazd University, Yazd, Iran \\ Poupak Alipour \\ Payam-e-Noor University of Arak, Arak, Iran \\ Shouket Ahmad Tilwani \\ Prince Sattam Bin Abdulaziz University, Alkharj, Saudi Arabia
}

\begin{abstract}
This study investigated the impact of spaced and massed instruction on foreign language reading motivation and reading attitude among Iranian pre-intermediate EFL learners. To fulfil this objective, 60 Iranian participants were chosen among 120 students based on the results of Oxford Quick Placement Test (OQPT). The selected pre-intermediate participants were then divided into two equal experimental groups: spaced group and massed group. Afterwards, the researcher measured the participants' reading motivation and reading attitude by administering a reading motivation questionnaire and a reading attitude survey as a pre-test. Then, both groups received the treatment. During the treatment phase of the study, the massed group was taught the reading comprehension in an intensive 60-minute session, while the spaced group was taught in three short sessions (twenty-minute session). After the instruction, a reading motivation questionnaire and a reading attitude survey as a post-test were carried out to both groups and finally the data were analyzed by running paired and independent sample t-tests. The outcomes demonstrated that there was a significant difference between the post-tests of spaced and massed groups. The findings indicated that the spaced group significantly out performed the massed group $(p<.05)$ on the reading motivation and reading attitude post-test. The implications of this study make teachers know that teaching through spaced periods can produce better outcomes than teaching through one massed session. Key words: massed instruction, spaced instruction, vocabulary learning, foreign language reading motivation, reading attitude, pre-intermediate EFL learners
\end{abstract}




\section{Introduction}

Undoubtedly, no one can deny that reading is one of the most valuable skills, particularly in foreign language environments where accessibility to a foreign language is mainly restricted to a written language. Reading is the easiest and most effective way to get information. Through reading, the reader can expand their understanding, widen their points of view and help them learn and understand more things about the universe (Penjak \& Karninčić, 2017). It is one of the most essential goals of learning. For children and adults, reading skills can open up a wide variety of possibilities and viewpoints on the new world. It helps them learn new skills, keep them up-to-date with information and technologies, enjoy literature and do their everyday jobs, which are important aspects of modern life (Okuniewski, 2014).

In formal language learning classroom, reading is the most important activity. It is not only a source of knowledge and pleasant practice, but also a medium for leveraging and expanding knowledge of the language. In other words, reading exercises will provide learners with many advantages, such as knowledge, enjoyment and information. Through this way, learners are not only able to read, but are also able to understand the written text of reading materials from books, journals, newspapers, and science and technology (Penjak \& Karninčić, 2017).

In the language learning process, particularly for learners of English as a Foreign Language, reading plays a fundamental role. According to Bánhegyi and Nagy (2019), reading is the most significant element for learners to improve their L2 competence. It has also become the main platform and the largest L2 input source. In addition, through reading, students can expand their understanding of the language in terms of syntax, discourse structure and vocabulary. These days, reading is perceived as an unpleasant and inappropriate practice for learners. Some scholars believe that students do not read their textbook even if they are aware of its effectiveness (Kwedlju as cited in Masduqi, 2014). Some others report that the loss of participation among learners in reading classes is due to the absence of understanding of the subject and the interpretation of the texts (Rukmini as cited in Masduqi, 2014).

Evidence that reading skills are essential to all educational stages and can result in good job chances (Esfandiari \& Hesani, 2019) has contributed to our curiosity in finding out the factors that contribute to the enthusiasm of reading and, in particular, L2 reading among learners.

Since reading is an essential language ability in the language learning process, it is crucial to enhance the reading activity of L2 learners. Motivation is a way to assist students to promote their understanding and desire to take part in reading courses. Komiyama (2013) mentions that reading is highly related to motivation because it inspires readers to learn and achieve their language learning goals. Motivation is a mixture of commitments to meet the goals of language learning (Meihami \& Saadat, 2019; Namaziandost, Sawalmeh, \& Izadpanah Soltanabadi, 2020).

Studies show that motivation is a fundamental element in the enthusiasm of readers. Baker and Wigfield (1999), for instance, examined the aspects of children's reading motivation and its relation to critical reading and success. The findings revealed that high reading motivation is related to the reading activity in terms of self-efficacy and difficulty, and the two inherent motivational aspects are linked to enthusiasm and participation. In addition, enthusiasm for reading is often reported as having an impact 
on reading development (Rigg \& van der Wal-Maris, 2020; Wang \& Guthrie, 2004). Apart from reading inspiration, reading attitude is another aspect that leads to learner's willingness to read as well as their ability to read (McKenna, Kear, \& Ellsworth, 1995; Jeon \& Yamashita, 2014).

Therefore, to increase the learner's foreign language reading motivation and reading attitude, the authors of the present study carried out spaced and massed instruction in Iranian EFL classrooms. Massed activity alludes to the circumstances under which learners continue to perform a task without rest. Spaced exercise refers to the circumstances under which learners are granted rest periods during practice sessions. Although information replicated in a scattered fashion or spaced over time is obtained more slowly, it is stored for much longer periods of time. The idea of the spacing effect, first explored by Ebbinghaus (Ebbinghaus, 1885) in 1885, is that, given the overall continuous study time, knowledge is better learned and stored when reviewed in staggered intervals rather than in one continuous study session. In order to recall knowledge, the spacing impact has been validated in a wide variety of learning realms, such as mathematics (e.g., Rohrer \& Taylor, 2006), children's development of L1 vocabulary (Childers \& Tomasello, 2002), the recollection of physical facts (Franzenburg, 2020) and the memorization of images (e.g., Toppino, 1993). The spacing impact has also been shown in the tasks of text processing (e.g., Seabrook, Brown, \& Solity, 2005).

To enhance intricate skills beyond simple memorization, the spacing effect is definitely efficient. In 1978, Baddeley and Longman discovered that the spacing effect was beneficial in participants' learning to touch type. Moreover, Rohrer and Taylor (2006) explored a major benefit in the use of spacing impact in intricate mathematical skills development. Moulton et al. (2006) observed that training a particular surgery procedure through spaced intervals (spaced distribution) created greater practice outcomes than training through one massed distribution practice session, as shown by a delayed post-test. Shebilske et al. (1999) noticed that learners better mastered the complicated challenge of computer simulation instruction by spaced delivery of practice sessions relative to mass distribution conditions. These results demonstrate that the Technique of Spacing Effects goes beyond mere rote memorization of information, and may lead to more nuanced learning efforts involving the incorporation of a variety of acquired skills.

According to cognitive psychology research, extensive practice is a situation in which the whole piece of teaching is presented in a continual period (Marco, Martinsone, \& Tali, 2020). As none of the language programs pursues completely extensive practice, the relation of cognitive psychology research concerning time allocation to language syllabus has been examined (Alipour, 2020; Serrano, 2011; William, Opoku, Saloviita, \& Tracey, 2020). According to Rohrer (2015), each language program is a distributed action. Nevertheless, frequent calls have been made to expand studies on the spacing effect from a laboratory setting to more real language learning conditions (Bird, 2010; Miles, 2014; Namaziandost, Saberi Dehkordi, \& Shafiee, 2019). Actually, when learning a language, one can imagine a wide range of time programs involving the length of different study periods, intermittent intervals, test delays and general training courses. Thus, the words "massed" and "distributed practice" are derived from cognitive psychology and used to explain situations in which training time is concentrated or distributed over a period of time. For instance, in Collins, Halter, Lightbown, and Spada's (1999) study, extensive training was used to refer to an intensive program in which the training time was focused on a 5 -month versus a 10 -month period. This definition of massed 
practice contradicts a study by Miles (2014), which refers to a situation in which 65 minutes of uninterrupted training is given. Consequently, due to the comparative nature of these terms, care should be taken when comparing the results of different studies on the distribution of training time.

The great benefits of using the spacing effect for complex numerical skill movement have been declared by Rohrer and Taylor (2006). Moulton et al. (2006) confirmed that training a particular medical procedure strategy through spaced intervals outperformed the results of training through an extensive circulatory training session, as shown in a month delayed post-test (Miles, 2014). According to Shebilske et al. (1999), learners learned an unpredictable PC recreation-preparing task better by divided allocation of training sessions in contrast to the extensive circulation periods. These results suggest that the method of separating effect goes beyond maintaining simple repetition of facts, and can aid in more confusing exercises, which need a combination of different scientific abilities.

The impacts of spaced training on reading comprehension have not been examined. Researchers, for example, Brantmeier (2003) and Namaziandost et al. (2020) have described reading cognition as an essential part of various exchanges of characteristic L2-related reading systems. Reading comprehension may vary among language learners. In this regard, Brantmeier (2003) acknowledged that processing similar or unexpected writings, learners could have unrecognizable translations. It means that learners may process the content accordingly; however, understand unexpectedly, or process the writings contrastingly, but comprehend in a similar way.

Numerous studies (Namaziandost, Nasri, Rahimi Esfahani, \& Keshmirshekan, 2019; Namaziandost, Rahimi Esfahani, \& Hashemifardnia, 2018; Mashhadi, Farvardin, \& Mozaffari, 2017; Schuetze, 2015; Miles, 2014; Xu, Padilla, \& Silva, 2012; Serrano, 2011) have investigated spaced and massed instruction. These studies lack straightforward and unmistakable findings. Language students in Serrano's (2011) study did not make greater growth in mass practice than did their intermediate equivalents. In a survey conducted by Xu et al. (2012) in the context of Mandarin intermediate level, $80+$ hours of training were offered over a 22 -week semester and a 4 -week intensive course. Unlike Serrano, this research found no disparity in improvements in oral understanding, vocabulary, pronunciation and grammar as a consequence of massed versus dispersed instruction. Despite these obstacles, the common agreement of all scholars studying language learning programs is that intensive programs are more efficient in promoting overall English proficiency. Thus, it is controversial how studies on the spaced effect in cognitive psychology will support planning decisions in foreign language study programs.

Meanwhile, a majority of studies have demonstrated the beneficial impacts of spaced instruction over massed instruction in grammar learning (Miles, 2014), vocabulary learning (Nakata, 2015), and reading skills (Seabrook, Brown, \& Solity, 2005). There is recent evidence that spaced distribution instruction is better than massed distribution instruction in the retention of target language structures, i.e., when learning is measured after administering a delayed post-test (Miles, 2014).

Investigating the great impacts of spacing on learning has been one of the significant fields of studies in psychological sciences pertinent to the spaced effect. The spaced effect refers to the advantage of memory, which increases memory when learning segments are extended for a long period of time rather than in a single session (Cepeda, Pashler, 
Vul, Wixted, \& Rohrer, 2006). Generally, it is essential to identify two kinds of repetitions: rehearsal and retrieval practice (Goossens, Camp, Verkoeijen, \& Tabbers, 2014; Namaziandost, Hafezian, \& Shafiee, 2018). Cognitive psychology studies have indicated that the use of retrieval practice results in better memory than restudy in the learning process (Roediger \& Karpicke, 2006). This situation is called the retrieval practice impact or testing effect. It refers to a memory phenomenon by which testing has a greater impact on memory than restudying.

However, the impact of spaced and massed instruction on reading motivation and attitude received little attention. In an effort to complete part of the existing gap, this study aimed to investigate if using spaced and massed instruction had any significant impact on foreign language reading motivation and reading attitude among Iranian pre-intermediate EFL learners.

A suitable level of education is regarded as one of the basic principles of sustainability that covers all skills and subskills of the language. On the other side, quality of education is based on the theory that educational goals are served and objectives achieved. For years, educating workforce had been the objective of education in Iran and in other countries as well. After that, the objective of the education changed within the economic domain to international economic competitiveness. Even though an economic situation has a significant effect on countries, communities, families and people, the focus appears to be moving from economic competitiveness towards global citizenship, social justice and sustainability.

In addition, a lasting enhancement is not achievable unless teachers and learners change their teaching and learning methods. In this respect, education has a crucial part in attaining sustainability. Based on Hofman-Bergholm (2018), sustainable education is inherently "value-dependent" (p. 25). Teachers and learners must be cognizant that their actions can influence the procedure of educational enhancement completely. If sustainable enhancement is understood as motivating sustainable shift in students, the duty of teacher must necessarily go beyond supplying the knowledge and the art of teaching to pre-service teachers since in this regard, teachers are regarded as agents of change rather than propagators of knowledge (Williams \& Burden, 1998). That is how the methods of educating obtain priority. Therefore, applying the suitable ways in educating by teachers may be useful for teacher-learner process of teaching since it provides teachers the chance to utilize their best ways to reach the best purposes (Kostoulas-Makrakis, 2010).

More significantly, education for sustainable enhancement assists learners in learning and constant comprehending of the educational facets, social sustainable enhancement and working accordingly (Anyolo, Karkkainen, \& Keinonen, 2018). Education for sustainable enhancement requires some learner-oriented strategies and interactive teaching practices such as spaced and massed instruction methods (Ichinose, 2017). Recently, some research studies have been performed on sustainable education and education for sustainable enhancement (Fedosejeva et al., 2018). Certainly, the education system plays a key role in teaching students and enhancing the effective teaching process.

Up to now, a large number of empirical studies related to memory analysis have revealed that spaced practice exceeds mass practice in learning. These studies have shown the advantageous impact of spacing in learning words (e.g., Gerbier, Toppino, \& Koenig, 2014; Goossens, Camp, Verkoeijen, Tabbers, \& Zwaan, 2014; Küpper-Tetzel, Erdfelder, \& Dickhäuser, 2014; Nakata, 2015; Namaziandost \& Çakmak, 2020), 
learning passages (e.g., Wang \& Guthrie, 2004), and learning L2 constructions (e.g., Matusevych, Alishahi, \& Backus, 2016). Despite the importance of spaced and massed instructions, they have not yet received the attention they deserve. In fact, only a few studies have examined the effectiveness of utilizing spaced and massed instructions in Iranian EFL context. Therefore, this study investigated the impacts of spaced and massed instructions on Iranian EFL learners' foreign language reading motivation and reading attitude.

Regarding the above-mentioned points, this study aimed to address the following questions:

RQ 1. Does spaced and massed instruction have any significant effect on the Iranian pre-intermediate EFL learners' foreign language reading motivation?

RQ 2. Does spaced and massed instruction have any significant effect on the Iranian pre-intermediate EFL learners' foreign language reading attitude?

\section{Methodology}

\section{Participants}

Based on the results of Oxford Quick Placement Test (OQPT), 60 pre-intermediate EFL learners were chosen among 120 Iranian learners from a private English language institute at the age from 16 to 18 years. Non-random convenience sampling was actually used. This study only included male learners with Persian as their native language. The selected learners were randomly divided into two equal experimental groups: spaced instruction and massed instruction.

\section{Instruments}

\section{Oxford Quick Placement Test (OQPT)}

OQPT was administered as the first instrument in the current study to homogenize the participants. In this study, 50 intermediate students were considered the target participants because based on the standards of OQPT those learners who got 30 to 39 points (out of 60) had a pre-intermediate level.

\section{The Motivation for Reading Questionnaire Used as Pre-test and Post-test}

A modified version of Motivation for Reading Questionnaire (MRQ) was the main instruments applied in the current study. In 1997, Dr. Allan Wigfield and Dr. John Guthrie from the University of Maryland developed the MRQ. During implementation of the Concept-Oriented Reading teaching, Wigfield and Guthrie applied the MRQ to a group of learners at one mid-Atlantic state school. Wigfield and Guthrie run factor analyses to verify the construct validity of 53 items in MRQ. The positive relevance of the maximum motivating reading fragments was low-to high-level. In addition, they reported that their questionnaire had a reliability ranging from .63 to .96. In this study, 30 of the 53 elements in the questionnaire were chosen by the researchers since only eight facets of the total eleven components of the motivation for reading were selected for measurement. They included: reading effectiveness, reading difficulty, reading curiosity, reading participation, reading value, reading a word-avoidance, social motives for reading, and grade reading. MRQ was a five-point Likert scale questionnaire made 
up of five choices: 1 for 'strongly agree', 2 for 'agree', 3 for 'do not know', 4 for 'disagree', and 5 for 'strongly disagree'. The MRQ administered two times, once prior the treatment and once after the treatment.

\section{Reading Attitude Survey}

To assess the participants' attitude toward reading, a reading attitude survey (RAS) adapted from "Survey of Adolescent Reading Attitude (SARA)" by Conradi et al. (2013, p. 569) was used. Each of the items started with the expression "How do you feel" and learners were requested to score each item according to a 4-point Likert scale from 'very good' to 'very bad.' The reliability coefficient (Cronbach's $\alpha$ ) of the attitude toward recreational reading items was 0.989 . The survey was translated into Persian, the learners' L1, and given to the researchers' advisors and EFL teachers for validation (content and face validity), and some revisions were made based on the comments. The reliability of the reading attitude survey of the Persian version was checked using Cronbach's alpha. Internal consistency coefficients of 0.982 were reliable. Like the MRQ, the RAS was given to learners two times, once prior the treatment and once after the treatment.

\section{Data Collection Procedure}

First of all, 120 Iranian EFL learners received the OQPT. Then, regarding their performance in the OQPT, 60 pre-intermediate learners were selected as the target participants of the study. After that, the researchers randomly divided the selected participants into two equal groups: spaced instruction group (SIG) and massed instruction group (MIG). Afterwards, the groups' foreign language reading motivation and reading attitude were measured by an MRQ and RAS as a pre-test. Next, participants in experimental groups obtained the same treatment, but in various ways. The reading comprehension was taught to the SIG and MIG through spaced instruction and massed instruction, respectively. The reading skills were taught to the learners during 60 minutes in a massed class. In fact, 60 minutes were dedicated to each session. In the spaced class, there were three sessions, and each session lasted 20 minutes. The spaced class took place three times a week, but the massed class took place once a week.

During the treatment, the MIG was taught reading comprehension in an intensive 60-minute session, while the SIG was taught in three short sessions (a total of 60 minutes). The first session lasted 20 minutes; while the second occurred two days after the initial session (lasted 20 minutes); and the third session lasted 20 minutes and was held two days after the second session.

The duration of the instruction was 15 sessions. The OQPT, MRQ and RAS were carried out in the first two sessions; the treatment was given to the students in the next eleven sessions, and finally the MRQ and RAS were administered as a post-test in the fourteenth and fifteenth sessions to the participants of both SIG and MIG to check their foreign language reading motivation and reading attitude after receiving the treatment. It means that after the intervention, the both groups were asked to fill out the motivation and attitude questionnaires. The MRQ and RAS contained 30 items and 5 items, respectively, designed to investigate the participants' motivation and attitude toward using the spaced and massed instruction after the intervention. 
Data Analysis

In this study, Statistical Package for Social Science (SPSS) software version 25 was used to analyze the data. First of all, the normality of the data was checked through running the Kolmogorov-Smirnov (K-S) test. Secondly, means and standard deviation as descriptive statistics were calculated. Ultimately, a paired sample t-test and an independent sample t-test were run to check the effects of the treatment on the learners' foreign language reading motivation and reading attitude.

\section{Results}

\section{Results of Normality Test}

Checking the normality of distributions is totally needed prior carrying our any analysis on a pre-test and post-test. Therefore, Kolmogorov-Smirnov test of normality was run (Table 1).

Table 1

One-Sample Kolmogorov-Smirnov Test (Groups' MRQ and RAS before and after the Treatment)

\begin{tabular}{lccc}
\hline & \multicolumn{3}{c}{ Kolmogorov-Smirnov $^{\mathrm{a}}$} \\
\cline { 2 - 4 } & Statistic & $\mathrm{df}$ & Sig. \\
\hline SIG. MRQ. Pre & .18 & 30 & .08 \\
\hline SIG. MRQ. Post & .24 & 30 & .09 \\
\hline SIG. RAS. Pre & .17 & 30 & .11 \\
\hline SIG. RAS. Post & .31 & 30 & .08 \\
\hline MIG. MRQ. Pre & .25 & 30 & .22 \\
\hline MIG. MRQ. Post & .22 & 30 & .11 \\
\hline MIG. RAS. Pre & .15 & 30 & .09 \\
\hline MIG. RAS. Post & .16 & 30 & .07 \\
\hline
\end{tabular}

Note. SIG: Spaced Instruction Group; MRQ: Motivation for Reading Questionnaire; Pre: Pretest; Post: Post-test; RAS: Reading Attitude Survey; MIG: Massed Instruction Group.

According to Table 1, all the $p$ values were higher than .05; thus, it could be inferred that the distributions of scores for the MRQ pre-test, MRQ post-test, RAS pre-test, and RAS post-test of both groups were normal. Thus, parametric tests (i.e., paired and independent sample t-tests in this case) were safe to use for comparing the groups.

\section{Results of Both Groups on MRQ as a Pre-test}

To compare the MRQ scores of the SIG and MIG learners prior the treatment, it was necessary to run an independent sample t-test (Tables 2 and 3).

Table 2

Descriptive Statistics Results Comparing SIG and MIG on MRQ Pre-test

\begin{tabular}{cccccc}
\hline & Groups & $\mathrm{N}$ & Mean & Std. Deviation & Std. Error Mean \\
\hline \multirow{2}{*}{ MRQ. Pre } & SIG & 30 & 38.80 & 5.32 & .97 \\
\cline { 2 - 6 } & MIG & 30 & 37.63 & 5.99 & 1.09 \\
\hline
\end{tabular}


The pretest mean scores of the SIG and MIG for MRQ are illustrated in Table 2. In foreign language reading motivation questionnaire, minimal differences can be seen between the mean scores of the two groups. An independent sample t-test was run to ascertain if there were any statistically significant differences (Table 3).

Table 3

Independent Sample t-Test Results Comparing SIG and MIG on MRQ Pre-test

\begin{tabular}{clcccccccc}
\hline & \multicolumn{1}{c}{$\begin{array}{c}\text { Levene's Test } \\
\text { for Equality } \\
\text { of Variances }\end{array}$} & & \multicolumn{4}{c}{ t-Test for Equality of Means } \\
\cline { 2 - 9 } MRQ. Pre & F & Sig. & t & df & $\begin{array}{c}\text { Sig. } \\
\text { (2-tailed) }\end{array}$ & $\begin{array}{c}\text { Mean } \\
\text { Difference }\end{array}$ & $\begin{array}{c}\text { Std. Error } \\
\text { Difference }\end{array}$ \\
\hline & $\begin{array}{l}\text { Equal variances } \\
\text { assumed }\end{array}$ & .23 & .63 & .79 & 58 & .42 & 1.16 & 1.46 \\
\hline $\begin{array}{l}\text { Equal variances } \\
\text { not assumed }\end{array}$ & & & .79 & 57.21 & .42 & 1.16 & 1.46 \\
\hline
\end{tabular}

The data demonstrated in Table 3 clearly indicate that no statistically significant difference can be found between the SIG and MIG on MRQ pre-test because the $p$ value (.42) was higher than the significance level $(p>.05)$. Accordingly, the researchers concluded that both groups were at the same level of MRQ prior the treatment.

\section{Results of Both Groups on RAS as a Pre-test}

Before implementing treatment, it was necessary to compare the RAS pre-test scores of SIG and MIG through an independent sample t-test to properly asses the homogeneity of both groups regarding their reading attitude.

Table 4

Descriptive Statistics Results Comparing SIG and MIG on RAS Pre-test

\begin{tabular}{cccccc}
\hline & Groups & $\mathrm{N}$ & Mean & Std. Deviation & Std. Error Mean \\
\hline \multirow{2}{*}{ RAS. Pre } & SIG & 30 & 21.66 & 7.20 & 1.31 \\
\cline { 2 - 6 } & MIG & 30 & 22.60 & 6.10 & 1.11 \\
\hline
\end{tabular}

Table 4 demonstrates the SIG and MIG learners' mean score on the RAS pre-test. An independent sample t-test was run to reveal if the difference between mean scores of both groups on RAS pre-test was statistically significant.

Table 5

Independent Sample t-Test Results Comparing SIG and MIG on RAS Pre-test

\begin{tabular}{clcccccccc}
\hline & & \multicolumn{3}{c}{$\begin{array}{l}\text { Levene's Test } \\
\text { for Equality } \\
\text { of Variances }\end{array}$} & & \multicolumn{4}{c}{$\mathrm{t}$-Test for Equality of Means } \\
\cline { 2 - 9 } & $\mathrm{F}$ & Sig. & $\mathrm{t}$ & $\mathrm{df}$ & $\begin{array}{c}\text { Sig. } \\
\text { (2-tailed) }\end{array}$ & $\begin{array}{c}\text { Mean } \\
\text { Difference }\end{array}$ & $\begin{array}{c}\text { Std. Error } \\
\text { Difference }\end{array}$ \\
\hline \multirow{2}{*}{ RAS. Pre } & $\begin{array}{l}\text { Equal variances } \\
\text { assumed }\end{array}$ & 1.75 & .19 & -.54 & 58 & .59 & -.93 & 1.72 \\
\cline { 2 - 9 } & $\begin{array}{l}\text { Equal variances } \\
\text { not assumed }\end{array}$ & & & -.54 & 56.45 & .59 & -.93 & 1.72 \\
\hline
\end{tabular}


Table 5 shows that no statistically significant difference exists in the mean scores of the SIG and MIG on RAS pre-test because the $p$ value was larger than $0.05(p>.05)$. Thus, it could be concluded that before the treatment both groups were at the same level of reading attitude.

\section{Results of Both Groups on MRQ as a Post-test}

Figuring out whether spaced and massed instruction had any significant effect on Iranian pre-intermediate EFL learners' foreign language reading motivation was the first research question in the current study. To reach a reasonable answer to this question, the SIG and MIG learners' MRQ posttest scores had to be contrasted through running an independent-sample t-test.

Table 6

Descriptive Statistics Results Comparing SIG and MIG on MRQ Post-test

\begin{tabular}{cccccc}
\hline & Groups & N & Mean & Std. Deviation & Std. Error Mean \\
\hline \multirow{2}{*}{ MRQ. Post } & SIG & 30 & 49.93 & 5.53 & 1.01 \\
\cline { 2 - 6 } & MIG & 30 & 38.33 & 5.19 & .94 \\
\hline
\end{tabular}

Regarding both groups' performance on MRQ post-test (see Table 6), it is obvious that the mean score of the SIG learners $(M=49.93)$ was higher than the mean score of the MIG learners $(M=38.33)$. An independent sample t-test was necessary to indicate if this difference was statistically significant.

Table 7

Independent Samples t-Test Results Comparing SIG and MIG on MRQ Post-test

\begin{tabular}{|c|c|c|c|c|c|c|c|c|}
\hline & & \multicolumn{2}{|c|}{$\begin{array}{l}\text { Levene's Test } \\
\text { for Equality } \\
\text { of Variances }\end{array}$} & \multicolumn{5}{|c|}{ t-Test for Equality of Means } \\
\hline & & $\mathrm{F}$ & Sig. & $\mathrm{t}$ & df & $\begin{array}{c}\text { Sig. } \\
\text { (2-tailed) }\end{array}$ & $\begin{array}{c}\text { Mean } \\
\text { Difference }\end{array}$ & $\begin{array}{l}\text { Std. Error } \\
\text { Difference }\end{array}$ \\
\hline \multirow{2}{*}{$\begin{array}{l}\text { MRQ. } \\
\text { Post }\end{array}$} & $\begin{array}{l}\text { Equal variances } \\
\text { assumed }\end{array}$ & 1.72 & .19 & 8.37 & 58 & .00 & 11.60 & 1.38 \\
\hline & $\begin{array}{l}\text { Equal variances } \\
\text { not assumed }\end{array}$ & & & 8.37 & 57.77 & .00 & 11.60 & 1.38 \\
\hline
\end{tabular}

Table 7 demonstrates that the difference between SIG $(M=49.93)$ and MIG $(M=38.33)$ on the MRQ post-test was statistically significant because the $p$ value was lower than $0.05(.00<.05)$. This reveals that utilizing the spaced instruction could enhance the SIG learners' reading motivation significantly.

\section{Results of Both Groups on RAS as a Post-test}

Regarding the second research question of this study which aimed to investigate if spaced and massed instruction had any significant effect on the Iranian pre-intermediate EFL learners' foreign language reading attitude, the reading attitude post-test of both SIG and MIG was compared using an independent sample t-test. 
Table 8

Descriptive Statistics Results Comparing SIG and MIG on RAS Post-test

\begin{tabular}{cccccc}
\hline & Groups & N & Mean & Std. Deviation & Std. Error Mean \\
\hline \multirow{2}{*}{ RAS. Post } & SIG & 30 & 34.26 & 2.62 & .47 \\
\cline { 2 - 6 } & MIG & 30 & 23.06 & 6.06 & 1.10 \\
\hline
\end{tabular}

Table 8 shows the descriptive statistics of both SIG and MIG on the RAS post-test. It is clearly seen that the means of the groups are different. The SIG had better performance than MIG. An independent sample t-test was run to indicate whether this difference was significant (Table 9).

Table 9

Independent Samples t-Test Results Comparing SIG and MIG on RAS Post-test

\begin{tabular}{|c|c|c|c|c|c|c|c|c|}
\hline & & \multicolumn{2}{|c|}{$\begin{array}{l}\text { Levene's Test } \\
\text { for Equality } \\
\text { of Variances }\end{array}$} & \multicolumn{5}{|c|}{ t-Test for Equality of Means } \\
\hline & & $\mathrm{F}$ & Sig. & $\mathrm{t}$ & $\mathrm{df}$ & $\begin{array}{c}\text { Sig. } \\
\text { (2-tailed) }\end{array}$ & $\begin{array}{c}\text { Mean } \\
\text { Difference }\end{array}$ & $\begin{array}{l}\text { Std. Error } \\
\text { Difference }\end{array}$ \\
\hline \multirow{2}{*}{ RAS. Post } & $\begin{array}{l}\text { Equal variances } \\
\text { assumed }\end{array}$ & 37.07 & .00 & 9.27 & 58 & .00 & 11.20 & 1.20 \\
\hline & $\begin{array}{l}\text { Equal variances } \\
\text { not assumed }\end{array}$ & & & 9.27 & 39.48 & .00 & 11.20 & 1.20 \\
\hline
\end{tabular}

Table 9 demonstrates the RAS post-test scores of SIG and MIG. As the score of SIG $(0.00)$ is smaller than .05 , significant difference between the groups is seen $(p<0.05)$. The SIG got better grades on the RAS post-test. It can be deduced that the implementing the treatment (using spaced instruction) affected the performance of the SIG on the reading attitude post-test more positively.

To find out whether the difference between the foreign language reading motivation and reading attitude pre-test and post-test scores of the SIG and MIG learners was statistically significant, a paired-sample t-test was run (Table 10).

Table 10

Results of Paired-Sample t-Test Comparing the Reading Motivation and Reading Attitude Pre-test and Post-test Scores of the SIG and MIG Learners

\begin{tabular}{|c|c|c|c|c|c|c|c|}
\hline & & Mean & $\begin{array}{c}\text { Std. } \\
\text { Deviation }\end{array}$ & $\begin{array}{l}\text { Std. Error } \\
\text { Mean }\end{array}$ & $t$ & $\mathrm{df}$ & $\begin{array}{c}\text { Sig. } \\
\text { (2-tailed) }\end{array}$ \\
\hline Pair 1 & $\begin{array}{l}\text { SIG. MRQ. Post - } \\
\text { SIG. MRQ. Pre }\end{array}$ & 11.13 & 7.98 & 1.45 & 7.64 & 29 & .00 \\
\hline Pair 2 & $\begin{array}{l}\text { SIG. RAS. Post - } \\
\text { SIG. RAS. Pre }\end{array}$ & 12.60 & 8.38 & 1.53 & 8.23 & 29 & .00 \\
\hline Pair 3 & $\begin{array}{l}\text { MIG. MRQ. Post - } \\
\text { MIG. MRQ. Pre }\end{array}$ & .70 & 1.60 & .29 & 2.39 & 29 & .07 \\
\hline Pair 4 & $\begin{array}{l}\text { MIG. RAS. Post - } \\
\text { MIG. RAS. Pre }\end{array}$ & .46 & .86 & .15 & 2.97 & 29 & .06 \\
\hline
\end{tabular}


Based on the data illustrated in Table 10, a significant difference can be seen between the MRQ pre-test $(M=38.80)$ and MRQ post-test $(M=49.93)$ of the SIG learners because the $p$ value was smaller than the significance level $(.00<.05)$. In addition, the difference between the RAS pre-test $(M=21.66)$ and RAS post-test $(M=34.26)$ of the SIG learners was of statistical significance since the $p$ value was smaller than the significance level $(.00<.05)$. Regarding the MIG group's performance on MRQ pretest and MRQ post-test and RAS pre-test and RAS post-test, no significant difference can be found as the $\mathrm{p}$ values were higher than $0.05(.07$ and $.06>.05)$. Thus, the researchers concluded that applying spaced instruction in the SIG classroom affected both reading motivation and reading attitude positively.

In brief, the required data were analyzed via means of independent and paired ttest samples. The findings revealed that the spaced group progressed on their MRQ and RAS post-test relative to their MRQ and RAS pre-test. Their post-test results were much higher than their pre-test grades. This enhancement may be the product of the spaced instruction. The outcomes of this survey are consistent with Year (2009) who explored the crucial role of the spaced effect in learning grammar. The findings showed that the spaced group greatly surpassed the massed group in the productivity and acceptability decision tests.

Spaced training helped the Iranian EFL students boost their reading enthusiasm and reading attitude. In spaced training, participants had more time to relax, more time to reflect, and more time to learn; this could relate to learners' desire to learn and their attitude to reading.

The findings of this research are confirmed by Bird (2010) who studied the impact of direct L2 grammar training through spaced method of teaching. This research demonstrated that the spaced group had better performance than the massed group.

In addition, after evaluating the results, the consequences revealed that the massed group did not increase their MRQ and RAS post-test as opposed to their pre-test. Their grades for the MRQ and RAS pre-test and post-test were approximately equal.

The findings of this research are consistent with Sobel et al. (2011) who had 39 middle-school children and learned eight new English words over two sessions with a one-week break among study sessions. Children also learned the vocabulary under two separate working circumstances (massed vs. spaced). The findings found that the recall of spaced items was considerably stronger than the recall of massed items.

The results of this research were confirmed by Lotfolahi and Salehi (2017), who applied a novel approach to classify various timeframes for space in young EFL students. To this end, young EFL participants were taught English-Farsi words utilizing various spacing plans (massed vs. spaced). The results found that spaced training provided greater long-term retention than massed one.

Learning content over two or three sessions that are divided (i.e., staggered or dispersed) in time also results in greater positive effects than devoting the same period of time learning the subject in one session.

The more spaced two objects are, the more probably they would be interpreted separately in the respondent's memory, as per the encoding heterogeneity hypothesis (Anderson \& Bower, 1972). This inconsistency in retrieval cues and encoding, which is promoted by the various ways in which the spaced elements occur, offers additional retrieval clues. As a result, recalling is preferred in the spaced distribution instruction. In addition, as per the defective processing model, in the spaced periods, the first demons- 
tration is not widely available at the time of the second demonstration, and the complete processing of the second presentation is therefore required (Fernbach, 2020). As a consequence, this method, in essence, encourages learning and knowledge retention. In essence, it is considered that when respondents are presented to two objects at the same time or within a brief period of time, they do not pay as much attention to these objects as when they are faced with ample spacing.

The findings of this study are in line with those of Mashhadi and Farvardin (2017) who examined effects of spaced and massed distribution instruction on EFL learners' recall and retention of grammatical structures. The findings of their study showed that on the delayed post-test the spaced group performed better than the other two groups. However, on the immediate posttest, no statistically significant difference was found between the spaced group and massed one.

\section{Conclusion}

The finding of this research demonstrated that spacing training contributed to stronger learning than massed training. The results showed that the spaced group performed better on reading motivation and reading attitude post-test since they received the spaced training. According to the results obtained, it can be inferred that learning via spaced delivery training allows students to maintain an adequate amount of information acquired from training before the next chance for review occurs, either inadvertently via input, deliberately through extra education, or through the necessity to utilize a particular item in speaking, reading, etc. (Miles, 2014, p. 421).

There are several advantages to the academic field of foreign language learning, particularly reading comprehension, from the incorporation of spaced teaching. Using the spaced training definitely increases the students' self-confidence in learning reading comprehension. The results of this study demonstrated that the English language learners should actively utilize spaced training to control their development and enhance their learning.

The outcomes of this survey would enable educators to educate their learners via spaced teaching, since this method of teaching is more efficient than the massed one. The outcomes will help English teachers utilize spaced instruction or massed instruction. With the insights obtained from this research, L2 instructors, analysts and curricula developers will be able to obtain information on how to promote the instruction of the English language via reading motivation and reading attitude through implementing spaced instruction and massed instruction.

Last but not least, sustainability is a problematic for every educational program. However, the literature directs us to a variety of main considerations that make it intuitive and feasible. First, sustainability is considered the main element of the process of implementation - a level at which the currently popular reading instruction program, which was specifically created, continues to evolve and increase students' achievement. Second, the appropriate instructional approaches should be developed to promote the purpose of high reading success and be faithful to the key components of evidence-based reading activities. Finally, it is necessary to make an immediate effort to schedule and assess sustainability.

During the time of this study, the researchers faced some limitations. Due to time limitation, only 60 learners took part in this study. This study was conducted on male 
students and the female students were overlooked. The other limitation referred to the treatment duration which was short. This study was restricted to the Iranian EFL respondents; it could be executed in other settings of the EFL and the ESL. The current research was performed on the Iranian pre-intermediate EFL students, so the outcomes should be very cautiously extrapolated to all language participants. The other constraint was that the research involved only students aged 16 to 18 years. The findings cannot, however, be extended to the other age groups.

\section{References}

Alipour, P. (2020). A comparative study of online vs. blended learning on vocabulary development among intermediate EFL learners. Cogent Education, 7(1), 1857489. Retrieved from https://doi.org/10.1080/2331186X.2020.1857489

Anderson, J. R., \& Bower, G. H. (1972). Recognition and retrieval processes in free recall. Psychological review, 79(2), 97-123.

Anyolo, E. O., Karkkainen, S., \& Keinonen, T. (2018). Implementing education for sustainable development in Namibia: School teachers' perceptions and teaching practices. Journal of Teacher Education for Sustainability, 20(1), 64-81.

Baddeley, A. D., \& Longman, D. J. A. (1978). The influence of length and frequency on training sessions on the rate of learning to type. Ergonomics, 21, 627-635.

Baker, L., \& Wigfield, A. (1999). Dimensions of children's motivation for reading and their relations to reading activity and reading achievement. Reading Research Quarterly, 34, 2-29.

Bánhegyi, M., \& Nagy, J. (2019). Teaching cultural differences through Korean Canadians: teaching material development for English as a foreign language classes. Acta Educationis Generalis, 9(3), 41-65.

Bird, S. (2010). Effects of distributed practice on the acquisition of second language English syntax. Applied Psycholinguistics, 31(4), 635-650.

Brantmeier, C. (2003). Does gender make a difference? Passage content and comprehension in second language reading. Reading in a Foreign Language, 15, 1-27.

Cepeda, N. J., Pashler, H., Vul, E., Wixted, J. T., \& Rohrer, D. (2006). Distributed practice in verbal recall tasks: A review and quantitative synthesis. Psychological Bulletin, 132, 354-380.

Childers, J., \& Tomasello, M. (2002). Two-year-olds learn novel nouns, verbs, and conventional actions from massed or distributed exposures. Developmental Psycho$\log y, 38,697-978$.

Collins, L., Halter, R., Lightbown, P., \& Spada, N. (1999). Time and the distribution of time in L2 instruction. TESOL Quarterly, 33(4), 655.

Conradi, K., Jang, B. G., Bryant, C., Craft, A., \& McKenna, M. C. (2013). Measuring adolescents' attitudes toward reading: A classroom survey. Journal of Adolescents and Adult Literacy, 56(7), 565-576.

Ebbinghaus, H. (1885). Trans. 1913. In Ruger, H. A., \& Bussenius, C. E. (Eds.), Memory: A contribution to experimental psychology (pp. 621-633). New York: Teachers College.

Esfandiari, R., \& Hesani, S. (2019). Willingness to communicate, possible selves, learner autonomy, and academic target needs: Implications for sustainable development in L2 pedagogy. Journal of Teacher Education for Sustainability, 21(2),121-138. 
Fedosejeva, J., Boče, A., Romanova, M., Iliško, D., \& Ivanova, O. (2018). Education for sustainable development: The choice of pedagogical approaches and methods for the implementation of pedagogical tasks in the anthropocene age. Journal of Teacher Education for Sustainability, 20(1), 157-179.

Fernbach, E. (2020). Social entrepreneurship education in art education of future primary school teachers. Discourse and Communication for Sustainable Education, 11(1), 26-40.

Franzenburg, G. (2020). Transforming paradigms of sustainable transcultural adult education. Discourse and Communication for Sustainable Education, 11(1), 16-25.

Gerbier, E., Toppino, T. C., \& Koenig, O. (2014). Optimising retention through multiple study opportunities over days: The benefit of an expanding schedule of repetitions. Memory, 23, 943-954.

Goossens, N. A., Camp, G., Verkoeijen, P. P., \& Tabbers, H. K. (2014). The effect of retrieval practice in primary school vocabulary learning. Applied Cognitive Psycho$\log y, 28,135-142$.

Goossens, N. A., Camp, G., Verkoeijen, P. P., Tabbers, H. K., \& Zwaan, R. A. (2014). Spreading the words: A spacing effect in vocabulary learning. Journal of Cognitive Psychology, 24, 965-971.

Hofman-Bergholm, M. (2018). Changes in thoughts and actions as requirements for a sustainable future: A review of recent research on the Finnish educational system and sustainable development. Journal of Teacher Education for Sustainability, 20(2), 19-30.

Ichinose, T. (2017). An analysis of transformation of teaching and learning of Japanese schools that significantly addressed education for sustainable development. Journal of Teacher Education for Sustainability, 19(2), 36-50.

Jeon, E. H., \& Yamashita, J. (2014). L2 reading comprehension and its correlates: A meta-analysis. A Journal of Research in Language Studies, 64(1), 160-212.

Komiyama, R. (2013). Factors underlying second language reading motivation of adult EAP students. Reading in a Foreign Language, 25(2), 149-169.

Kostoulas-Makrakis, N. (2010). Developing and applying a critical and transformative model to address education for sustainable development in teacher education. Journal of Teacher Education for Sustainability, 12(2), 17-26.

Küpper-Tetzel, C. E., Erdfelder, E., \& Dickhäuser, O. (2014). The lag effect in secondary school classrooms: Enhancing students' memory for vocabulary. Instructional Science, 42, 373-388.

Lotfolahi, A. R., \& Salehi, H. (2017). Spacing effects in vocabulary learning: Young EFL learners in focus. Cogent Education, 4, 1-10.

Marco, F., Martinsone, B., \& Tali, S. (2020). Promoting sustainable social emotional learning at school through relationship-centered learning environment, teaching methods and formative assessment. Journal of Teacher Education for Sustainability, 22(1), 21-36.

Masduqi, H. (2014). EFL reading in Indonesian universities: Perspectives and challenges in cultural contexts. Journal of Teaching and Education, 3(03), 385-397.

Mashhadi, A., \& Farvardin, M. T. (2017). Effects of spaced and massed distribution instruction on EFL learners' recall and retention of grammatical structures. Teaching English Language, 11(2), 57-75. 
Matusevych, Y., Alishahi, A., \& Backus, A. (2016). The impact of first and second language exposure on learning second language constructions (pp. 1-22). Bilingualism: Language and Cognition.

Meihami, H., \& Saadat, M. (2019). An investigation into the effects of prompt selection on writing complexity, accuracy, and fluency: The case of Iranian learners at different proficiency levels. Journal of Language and Cultural Education, 7(3), 79-96.

Miles, S. (2014). Spaced vs. massed distribution instruction for L2 grammar learning. System, 42, 412-428.

Moulton, C. E., Dubrowski, A., MacRae, H., Graham, B., Grober, E., \& Reznick, R. (2006). Teaching surgical skills: What kind of practice makes perfect? Annals of Surgery, 244, 400-409.

Nakata, T. (2015). Effects of expanding and equal spacing on second language vocabulary learning. Studies in Second Language Acquisition, 37(4), 677-711.

Namaziandost, E., \& Çakmak, F. (2020). An account of EFL learners' self-efficacy and gender in the Flipped Classroom Model. Education and Information Technologies, 25(2), 4041-4055. Retrieved from https://doi.org/10.1007/s10639-020-10167-7

Namaziandost, E., Nasri, M., Rahimi Esfahani, F., \& Keshmirshekan, M. H. (2019). The impacts of spaced and massed distribution instruction on EFL learners' vocabulary learning. Cogent Education, 6(1), 1661131. Retrieved from https://doi.org/10.1080/ 2331186X.2019.1661131

Namaziandost, E., Hafezian, M., \& Shafiee, S. (2018). Exploring the association among working memory, anxiety and Iranian EFL learners' listening comprehension. AsianPacific Journal of Second and Foreign Language Education, 3(20), 1-17. Retrieved from https://doi.org/10.1186/s40862-018-0061-3

Namaziandost, E., Rahimi Esfahani, F., \& Hashemifardnia, A. (2018). The comparative effect of spacing instruction and massed instruction on intermediate EFL learners' reading comprehension. SAGE Open, 8(4), 1-8. Retrieved from https://doi.org/ $10.1177 / 215824401881102$

Namaziandost, E., Razmi, M. H., Heidari, S., \& Tilwani, S. A. (2020). A contrastive analysis of emotional terms in bed-night stories across two languages: Does it affect learners' pragmatic knowledge of controlling emotions? Seeking implications to teach English to EFL learners. Journal of Psycholinguistic Research, 49(6), 10471065. Retrieved from https://doi.org/10.1007/s10936-020-09739-y

Namaziandost, E., Saberi Dehkordi, E., \& Shafiee, S. (2019). Comparing the effectiveness of input-based and output-based activities on productive knowledge of vocabulary among pre-intermediate EFL learners. Asian-Pacific Journal of Second and Foreign Language Education, 4(2), 1-14.

Namaziandost, E., Sawalmeh, M. H. M., \& Izadpanah Soltanabadi, M. (2020). The effects of spaced versus massed distribution instruction on EFL learners' vocabulary recall and retention. Cogent Education, 7(1). Doi: 10.1080/2331186X.2020.1792261

Okuniewski, J. E. (2014). Age and gender effects on motivation and attitudes in German learning: The Polish context. Psychology of Language and Communication, 8(3), 251-262.

Penjak, A., \& Karninčić, H. (2017). National identity and language: Students' usage of English terminology within the Croatian language. Journal of Language and Cultural Education, 5(2), 40-52. 
Rigg, E., \& van der Wal-Maris, V. (2020). Student teachers' learning about social entrepreneurship education - a Dutch pilot study in primary teacher education. Discourse and Communication for Sustainable Education, 11(1), 41-52.

Roediger, III, H. L., \& Karpicke, J. D. (2006). The power of testing memory: Basic research and implications for educational practice. Perspectives on Psychological Science, 1, 181-210.

Rohrer, D., \& Taylor, K. (2006). The effects of overlearning and distributed practice on the retention of mathematics knowledge. Applied Cognitive Psychology, 20, 1209-1224.

Schuetze, U. (2015). Spacing techniques in second language vocabulary acquisition: Short-term gains vs. Long-term memory. Language Teaching Research, 19(1), 28-42.

Seabrook, R., Brown, G. D. A., \& Solity, J. E. (2005). Distributed and massed practice: From laboratory to classroom. Applied Cognitive Psychology, 19, 107-122.

Serrano, R. (2011). The time factor in EFL classroom practice. Language Learning, 61(1), 117-145.

Shebilske, W. L., Goettl, B. P., Corrington, K., \& Day, E. A. (1999). Inter-lesson spacing and task-related processing during complex skill acquisition. Journal of Experimental Psychology: Applied, 5, 413-437.

Sobel, H. S., Cepeda, N. J., \& Kapler, I. V. (2011). Spacing effects in real-world classroom vocabulary learning. Applied Cognitive Psychology, 25, 763-767.

Toppino, T. C. (1993). The spacing effect in preschool children's free recall of pictures and words. Bulletin of the Psychonomic Society, 31, 27-30.

Wang, J. H., \& Guthrie, J. (2004). Modeling of effects of intrinsic motivation, extrinsic motivation, amount of reading, and past reading achievement on text comprehension between U.S. and Chinese students. Reading Research Quarterly, 39(2), 162-186.

Wigfield, A., \& Guthrie, J. T. (1997). Relations of children's motivation for reading to the amount and breadth of their reading. Journal of Educational Psychology, 89, 420-432.

William, N., Opoku, M. O., Saloviita, T., \& Tracey, D. (2020). Teacher educators' and teacher trainees' perspective on teacher training for sustainable development. Journal of Teacher Education for Sustainability, 22(1), 49-65.

Williams, M., \& Burden, R. (1997). Psychology for language teachers: A social constructivist approach. Cambridge: Cambridge University Press.

Xu, X., Padilla, A., \& Silva, D. (2012). The time factor in Mandarin language learning: The four-week intensive versus the regular high school semester. The Language Learning Journal, 42(1), 55-66.

Year, J. (2009). Korean speakers' acquisition of the English ditransitive construction: The role of input frequency and repetition. Unpublished doctoral dissertation, Teacher's College, Columbia University.

Correspondence concerning this paper should be addressed to Ehsan Namaziandost, Department of English, Shahrekord Branch, Islamic Azad University, Shahrekord, Iran. Email: e.namazi75@yahoo.com 